\title{
Analysis of Content and Discourse on Character Education in History Textbooks on Islamic History Materials
}

\author{
Lutfiah Ayundasari ${ }^{1}$, Ulfatun Nafi'ah ${ }^{2}$, Najib Jauhari ${ }^{3}$, Rica Filasari ${ }^{4}$ \\ ${ }^{1,2,3,4}$ Department of History, Universitas Negeri Malang, Malang, Indonesia \\ lutfiah.fis@um.ac.id, ulfatun.nafiah. fis@um.ac.id,najib.jauhari.fis@um.ac.id
}

\begin{abstract}
This study aims to analyze the content and discourse of character education in high school history textbooks on Islamic history material. This goal is motivated by concern for the tendency to diminish historical awareness about the socio-cultural process that accompanies the development of Islam in Indonesia so that it leads to the spread of radicalism in various circles. Through a study of its content, an understanding of the weaknesses and strengths of history textbooks will be obtained by high school students so that improvements can be made for the success of the golden generation of 2045. The research method used is a combination of two types of textbook analysis approaches namely didactic and content analysis. The results of this study indicate that in Indonesian Islamic history material textbooks do not contain the content needed to understand history holistically, the material is still developed based on the perspective of political history. While the most dominant character content is nationalism and friendly /communicative, on the other hand, there is a character content that is needed but there is no discipline, love peace, love to read and care for the environment.
\end{abstract}

Keywords: character education, history, Islamic history materials

\section{Introduction}

Textbooks are an important component in the learning process that embodies the curriculum which is often a representation of battles and compromises in politics, culture, economics, and politics[1][2]. ome of its functions include as a primary learning source, a complementary source, and inspiration for learning activities[3]. Besides, textbooks are also declared capable of forming students' whole human views and building peace[4][5]. Before the digital era, textbooks were the only source of learning that was used uniformly throughout Indonesia, whose management and preparation was under the control of the Ministry of Education and Culture.

In history textbooks, the narration that emerges is closely related to political interest, ideology, author's background, and educational standards, so they are often regarded as the highest memory and court of history agents.[5][6]. Although textbooks were once in an important position in education, now it's existence has begun to be questioned by the presence of various learning resources that are more attractive both print and electronic. In addition, the use of textbooks is traditional and only accommodates the need for low- and middle-level understanding, not for high-level understanding[7]. Therefore, many studies suggest a revision. 
In other countries, studies of textbooks have led to content revisions aimed at freeing the contents of studies from nationalistic, chauvinistic and interpretation bias themes to be directed at the theme of peace and international understanding[8][9]. This is done as a form of reconciliation, an example of a history textbook in America[6][10]. Considering various historical problems both in terms of politics, social and culture, it is time for the government to start updating the curriculum of history and textbooks so that it does not only discuss political history from one perspective. Discoveries in historical science should have been included in textbooks. his is following the opinion of Saveedra and Opfer which states that there are at least 9 things that must be developed in 21 st-century learning, one of which is, "make it relevant" [11].

In Indonesia, the study of history textbooks mostly discusses values representation, content evaluation, character content, and material content related to national values[12][13][14]. The textbook studies have not yet touched the realm of evaluation and the relevance of values and content to the new conditions in the 21 st century, especially on Islamic historical material. This study is important to discussgiven the increasingly widespread transnational religious notions in schools and universities[15][16][17]. Therefore, in this article, the author intends to evaluate the contents and contents of the characters contained in official history textbooks, especially on the material of Islamic history in Indonesia.

\section{Research Methods}

This study uses two types of textbook analysis approaches namely didactic and content analysis. The didactic approach is used to examine the educational content implicit in the text, while content analysis is used to examine the text[18]. Furthermore, the content analysis uses discourse analysiscritical model Roger Fowler et al. The main data sources used are Indonesian history textbooks for the 2013 curriculum revised 2017 class X, XI, and 2018 revised edition class XII published by the Ministry of Education and Culture of the Republic of Indonesia. Roger Fowler et al emphasized the vocabulary and grammar of the sentence in a language that is spoken[19]. There are two levels in the analysis model of Roger Fowler et al. The micro-level consists of words and sentences contained in the text, while the macro level is associated with history books and character education values related to Islamic history material. Vocabulary and grammar are used to see the reality that represents character education in Indonesian history textbooks, especially on Islamic history material.

This research focuses on the role of Muslims in history that illustrates the reality of events or actors who carry out actions and then write them down in text through language. Data collection techniques are carried using documentation. The researcher not only records the contents but also analyzes the meaning implicit in the fragment of the text. Character education in Indonesian history textbooks is represented in text through words and sentences. Data validity is done holistically (linking text with context.), Historical situatedness (placing what is studied in the context of historical situatedness that surrounds it), and theory (related to interpretation and explanation)[20]. 


\section{Results and Discussion}

\subsection{Trends in Character Content in Islamic History Materials}

Textbook analyzed in this studyis the history of Indonesia Curriculum 2013 revised edition 2017 published by the Ministry of Education and Culture Republic of Indonesia class X, XI, and 2018 edition for XII which can be downloaded on the page http://puskurbuk.kemendikbud.go.id. This textbook analysis study centers on the values of cultural education and national character consisting of: (1) religious, (2) honest, (3) tolerance, (4) discipline, (5) hard work, (6) creative, (7) independent, (8) democratic, (9) curiosity, (10) national spirit, (11) patriotism, (12) valuing achievement, (13) friendship / communicative, (14) peace love, (15) love to read, (16) care about the environment, (17) care about social, and (18) responsibility.

Analysis of this text is only carried out on Islamic history material, so that the analysis of this textbook is carried out per section. The details of the authors of each book analyzed are as follows: (1) Class X 2013 Curriculum 2013 revised edition 2017, written by Restu Gunawan, Amurwani Dwi Lestariningsih, Sardiman AM; (2) Class XI of the 2013 revised edition of the 2013 curriculum, written by Sardiman AM and Amurwani Dwi Lestariningsih; and (3) class XII Curriculum 2013 revised edition 2018, written by Abdurakhman, Arif Pradono, Linda Sunarti, and Susanto Zuhdi. Based on the research of critical discourse analysis by Roger Fowler et al, the results of the analysis are as shown in table 1.

Table 1. Recapitulation of Cultural Education Values and Nation Character in Indonesian High School History Textbooks on Islamic History Materials

\begin{tabular}{|c|c|c|c|c|c|c|}
\hline \multirow{2}{*}{ No } & \multirow{2}{*}{ Score } & \multicolumn{4}{|c|}{ Indonesian History Textbooks } & \multirow[b]{2}{*}{ total } \\
\hline & & $\mathbf{X}$ & XI Semester 1 & XI Semester 2 & XII & \\
\hline 1. & Religious & 5 & 1 & 1 & - & 7 \\
\hline 2. & Honest & 1 & 1 & - & - & 2 \\
\hline 3. & Tolerance & - & - & - & 2 & 2 \\
\hline 4. & Discipline & - & - & - & - & - \\
\hline 5. & Hard work & 1 & 1 & - & 1 & 3 \\
\hline 6. & Creative & - & 5 & - & - & 5 \\
\hline 7. & Independently & 1 & - & - & - & 1 \\
\hline 8. & Democratic & - & 1 & - & 2 & 3 \\
\hline 9. & Curiosity & 5 & 1 & - & - & 6 \\
\hline 10. & Spirit of nationality & 3 & 19 & 5 & 3 & 30 \\
\hline 11. & Nationalism & 1 & 2 & - & 4 & 7 \\
\hline 12. & Appreciate Achievement & - & - & 1 & 1 & 2 \\
\hline 13. & Friendly / Communicative & 9 & 9 & 7 & 4 & 29 \\
\hline 14. & Love peace & - & - & - & - & - \\
\hline 15. & Like to read & - & - & - & - & - \\
\hline & Environmental care & - & - & - & - & - \\
\hline 17. & Social care & - & 1 & 1 & - & 2 \\
\hline 18. & Responsible & - & 1 & 1 & 1 & 3 \\
\hline & Total & 26 & 42 & 16 & 18 & 102 \\
\hline
\end{tabular}

Based on the data in the table, it can be seen that not all values of cultural education and national character appear in Indonesian history textbooks on Islamic history material. The uneven distribution of the value of cultural education and national character depends on the content of the material presented per section.

Material content in the form of events, stories, or tragedies lacks vocabulary and grammar which implies all the values of cultural education and national character. In addition, the 
absence of some values of cultural education and national character can be caused by writers who only describe data and facts so they do not insert events, stories, or tragedies that imply character content. Even though the narrative with character content is very important to be written to be a medium for indirect values and moral cultivation. In addition, through these narratives, the teacher can elaborate historical material so that it is not dry and cognitive. In detail the characters contained in the textbook are presented in Figure 1.

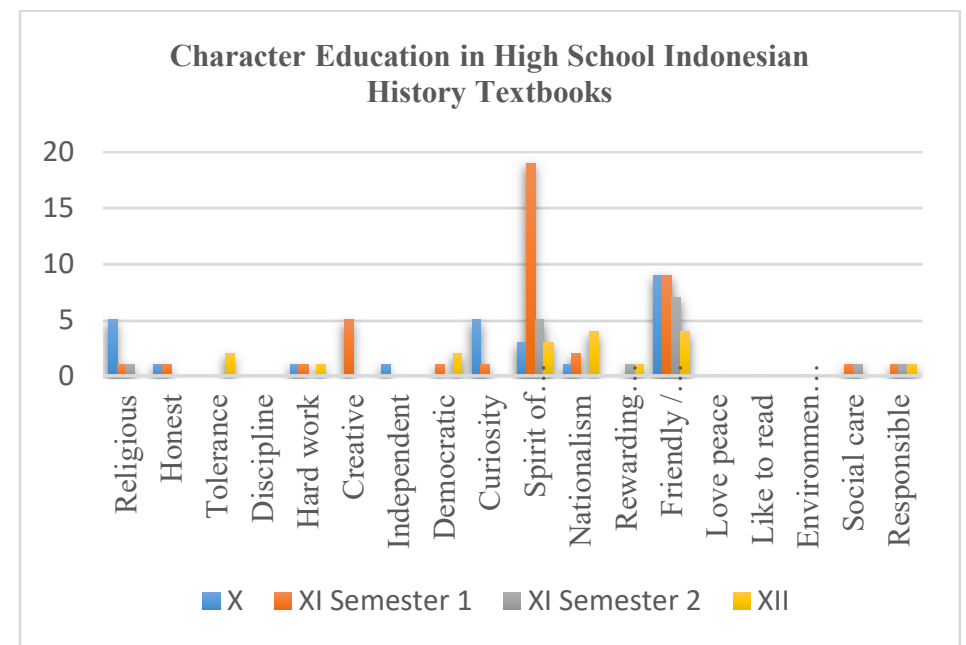

Fig.1. Values distribution of Cultural Education and Nation Character in Indonesian History Textbook on Islamic History Materials

Based on the data analysis results of the Roger Fowler et al model presented in Figure 1, it appears that only two valuesof character education that appear in each of the high school Indonesian history textbooks on Islamic history material are the spirit of nationality and friendly/communicative. The national spirit discourse is very dominant in writing textbooks that are useful for the formation of national and state character. The spirit of nationalism that boils down to nationalism is a way of thinking, behaving, and acting that shows loyalty, care and high respect for the language, physical, social, cultural, economic, and political environment of the nation, and places the interests of the nation and state above self-interest and his group[21]). This character becomes the most dominant and often appears in writing textbooks, especially in class XI both semester 1 and semester 2 . This can be understood because based on the content of the material presented in Indonesian history textbooks related to the role of Muslims during the struggle of the Indonesian nation to obtain independence.

The spirit of nationality referred to in class X and XI semester 1 textbook is associated with a feeling of unity and struggle when fighting against the occupation of the Dutch. The sultans and the Muslims in the textbook were narrated to help one another carry out the resistance, the rebellion, and the war against the Western powers. The resistance was motivated by the suffering and misery of the people against the Western policy. The emergence of ethical politics at the beginning of the 20th century in Indonesia became the starting point for the social change of the nation which is outlined in the textbook class XI semester 1 of the last chapter to class XII. During this national movement, a lot of vocabulary and grammar in sentences reflecting the character's content placed the interests of the nation and state above self and group interests. 
The second character is friendly/communicative. Based on the formulation of the Ministry of National Education (2010) friendly/communicative is an action that shows a sense of pleasure in talking, socializing, and cooperating with others. The vocabulary and grammar in many sentences reflect this value. Muslims in every textbook is described as having friendly/communicative character values. This is evident in his attitude and behavior in all aspects of life. From the economic point of view, the sultans and their people easily cooperated with traders who came and even sent goods abroad to develop the economy of their region. From a political perspective, the sultans and Islamic fighters cooperated with the people or even allied with foreign nations to fight against the arbitrary authority of the Dutch at that time.

Friendly/communicative can be associated with the value of mutual cooperation. This value reflects action and context that have the same meaning as cooperation and help. This value has been the culture of people in the world since prehistoric times until now. This shows that no human being can survive alone so that the spread of friendly/communicative values is evenly distributed in each textbook.

\subsection{Evaluation of the Suitability of Content and Content of Character with Current Conditions}

Indonesian history textbooks that are used as learning resources in the 2013 curriculum are published by the Ministry of Education and Culture in the form of e-books and printed books. The material contained in it similar with previous books that contain about the history of Indonesia from the pre-litera to reformation. In addition there are also specialization history books issued by several publishers such as Mediatama and Yrama Widya. The textbook was developed in accordance with the applicable curriculum. Although there is more space in the curriculum history of specialization, but little new content has emergedin the material presentation.

The material in history textbooks tends to be rigid and contains facts which are repetition of historical material that has been received at the previous level. This is the background of the opinion that textbooks only provide a means for low-level thinking. Whereas at the level of secondary education for learning history, it has to reach a critical stage and high order thinking so students do not only understand an event from one perspective. Learning history should be able to enrich student understanding by providing a window into the dilemmas, choices and beliefs of people in the past [20]. This is expected to be able to foster critical thinking skills where these skills can be applied in everyday life. One way to achieve this goal is to include new features in textbooks containing current events as a basis for past explanations or vice versa. However, most textbooks do not use present conditions as a basis for explanations of the past [21].

This condition also occurs in Indonesian history textbooks whose focus revolves around the facts of the past without giving students access to understand their relevance to the present. In addition, the textbook also does not present material based on a multidimensional and interdisciplinary approach that helps students to understand historical events holistically. The revision of the presentation of historical material, including Islamic history, is considered important so that students do not feel stuttering in the face of phenomena that are actually repeated patterns in history such as the existence of peaceful penetration through acculturation and assimilation as well as penetration of violence. Learning the reality of history in real terms at the upper secondary level will train them to determine attitudes towards an event, 
In addition to material content / content, a revision that needs to be done in Islamic history textbooks in Indonesia is the addition of character content. This is important because based on the results of research that the integration of educational values in textbooks has an impact on student character [24]. The integration of character education in textbooks must be done seriously because the role of textbooks is still very calculated even at the university level because it is considered capable of forming students' views holistically [4]. Cultivation of character in the world of education is considered very important because education must be able to guarantee the sustainability of peace, contribute to fostering a love for peace, foster and increase tolerance, mutual respect, and reject the spread of negative stereotypes[6][22][23].

Based on the previous discussion found evidence that the contents of the textbook history of Islamic History in Indonesia mostly focus on nationalism and friendly / communicative. While other values such as discipline, peace, reading, and caring for the environment do not get a place at all. Whereas the four contents of the character are expected to be able to change the perception of the younger generation about the face of Islam in the past so that they can determine their attitude in facing the swift flow of information related to the development of Islam today. The revision of character content must be appropriate in the context of the right situation to encourage a more complex understanding of "the other" because we live in a multicultural society.

Discipline is an action that shows orderly and compliant behavior in various provisions and regulations (Ministry of National Education, 2010). This character content does not appear in the textbook at all, because the content of the material that is centered on the role of Muslims in history does not show this character. In fact, the success of the spread of Islam, the struggle against the invaders, and the increase in human resources both religious and academic, depends on the discipline of the narrators of the narrated history. Like the content of disciplined characters, in writing Indonesian history textbooks also does not bring up the content of peace-loving characters. This character is less explicitly reviewed in historical narratives in textbooks.

Another character that never appears is fond of reading and caring for the environment. Development of material that is still focused on political history causes students not to get stories about humanist figures who are enthusiastic in seeking knowledge such as Sheikh Muhammad Nawawi al-Jawi al-Bantani, Ahmad Khatib as-Sambasi, Muhammad Mahfudz atTarmasi, or the story of how militant Abdurahman Wahid in reading and seeking knowledge. The character of caring for the environment can be elaborated even further by displaying the reasons why religious leaders and Muslims are willing to fight for their homeland. Presentation of material from various perspectives will give a complete picture that the struggle against the invaders is not only about the struggle for hegemony but about how to create a safe and peaceful environment so as to create comfort in worship.

Other major work that needs to be done in revising textbooks is not only about material content and correction of factual errors and characters but also must explore the links between socio-historical, ideological and geo-political influences [2]. In addition, the integration of 21 st century characters, namely mindfulness, curiosity, courage, resilience, ethics, and leadership[24]. This work certainly will not be completed in a short time, but must begin immediately given the tendency of the depletion of historical awareness about the sociocultural process of the development of Islam in Indonesia to the end of the understanding of radicalism. This can be started from the smallest and easiest environment, each class. The 2013 curriculum has provided wide scope for history teachers to improvise learning according to their needs. Through this paper the researcher hopes that growing awareness about the need 
for revision of content and character content in textbooks will stimulate the reader to take innovative steps that are important for the success of the golden generation of 2045 .

\section{Conclusion}

Based on the research that has been done, it can be concluded that the content and discourse of character education in high school history textbooks on Islamic history material still needs to be revised. The material developed in the textbook is mostly examined from the perspective of political history. This is actually not in line with the development of historical science in Indonesia which has used an interdisciplinary and multidimensional approach in analyzing historical events. Descriptions of historical events from only one perspective have an impact on students' partial understanding and tend to train students to think lower level. Even though at the high school level students must be introduced to critical thinking skills. In addition to revisions to the content, what needs to be done is to revise the character content because based on the results of the study it was found that the dominant character content is nationalism and communicative / friendly in the context of physical struggle. Both of these character loads are important, but they are not in line with the challenges facing the Indonesian people today, namely the spread of radicalism and transnationalism. There are contents that do not appear in the text, namely discipline, love peace, love to read, and care for the environment.

\section{Reference}

[1] M. Repoussi and N. Tutiaux-Guillon, "New trends in history textbook research: Issues and methodologies toward a school historiography," J. Educ. Media, Mem. Soc., vol. 2, no. 1, pp. 154-170, 2010.

[2] K. Crawford, "Researching the Ideological and Political Role of the History Textbook - Issues and Methods," pp. 1-8, 1993.

[3] D. Garinger, "Textbook Selection for the ESL Classroom," CAL Dig., no. December 2002, p. 3, 2002.

[4] EI Nikonova, IA Sharonov, SN Sorokoumova, OV Suvorova, and EA Sorokoumova, "Modern functions of a textbook on social sciences and humanities as an informational management tool of university education," Int. J. Environ. Sci Educ., vol. 11, no. 10, pp. 3764-3774, 2016.

[5] Z. Wang, "Old wounds, new narratives: Joint history textbook writing and building in East Asia," Hist Mem, vol. 21, no. 1, pp. 101-126, 2009.

[6] F. Pingel, "Can truth be negotiated? History textbook revision as a means to reconciliation, "Ann Am Acad. Pol. Soc. Sci, vol. 617, no. 1, pp. 181-198, 2008.

[7] KH Lau, T. Lam, BH Kam, M. Nkhoma, J. Richardson, and S. Thomas, "The role of textbook learning resources in e-learning: A taxonomic study," Comput Educ., vol. 118, pp. 10-24, 2018.

[8] E. Fuchs, "Current Trends in History and Social Studies Textbook Research," J. Int. Coop Educ., vol. 14, no. 2, pp. 17-34, 2011.

[9] RL Hughes, "A Hint of Whiteness: History Textbooks and Social Construction of Race in the Wake of the Sixties," Soc. Stud, vol. 98, no. 5, pp. 201-208, 2007.

[10] J. DeRose, "Comparing International Textbooks to Develop Historical Thinking.," Soc. Educ., vol. 71, no. 1, pp. 36-39, 2007.

[11] AR Saavedra and V. Darleen Opfer, "Learning 21st-century skills requires 21st-century teaching, "Phi Delta Kappan, vol. 94, no. 2, pp. 8-13, 2012. 
[12] IWP Utami and AN Widiadi, "Unity in Diversity Discourse in History Textbooks," Paramita Hist. Stud J., vol. 26, no. 1, p. 106, 2016.

[13] H. Purwanta, "Evaluation of the Content of History Textbooks in the New Order," J. Horizon Educators., no. 3, pp. 424-440, 2013.

[14] Main EJPU, "Historical Material in West Kalimantan Multicultural Education Local Content Textbooks," SOCIA J. The Social Sciences., vol. 10, no. 2, 2015.

[15] S. Rijal, "Radicalism of Young Muslims Educated in Makassar," Al-Qalam, vol. 23, no. 2, 2017.

[16] Z. Qodir, "Youth, Religious Intolerance and Radicalism," J. Stud. Young man, vol. 5, no. 1, p. 429, 2018.

[17] HA Sanaky and E. Safitri, "Religious Radicalism in the Perspective of Education," Millah, vol. XIV, no. 2, pp. 135-146, 2016.

[18] F. Pingel, UNESCO guidebook on textbook research and textbook revision (2nd revised and updated ed.). Paris: United Nations Educational, Scientific and Cultural Organization, and the Georg Eckert Institute for International Textbook Research, 2010.

[19] Eriyanto, Discourse Analysis: Introduction to Media Text Analysis. Yogyakarta: LKIS, 2011.

[20] I. Hamad, "Development of Discourse Analysis in Communication Science." 2012.

[21] Ministry of Education and Culture, "Concepts and Guidelines for Strengthening Character Education," Ministry of Education and Culture, p. 58, 2017.

[22] V. Greaney, Textbooks, respect for diversity, and social cohesion. 2006.

[23] M. (Ed) Riley, Guidebook for History Textbooks Authors. .

[24] M. Bialik, C. Fadel, B. Trilling, P. Nilsson, and J. Groff, "21st Century Skills: What should students learn?" May, 2015. 